\title{
A Genetic Linkage Map for Watermelon Derived from Recombinant Inbred Lines
}

\author{
Renbing Zhang, Yong Xu, ${ }^{1}$ Ke Yi, Haiying Zhang, Ligong Liu, and Guoyi Gong \\ National Engineering Research Center for Vegetables, Beijing 100089, China \\ Amnon Levi \\ U.S. Department of Agriculture, Agricultural research Service, U.S. Vegetable Laboratory, 2700 \\ Savannah Highway, Charleston, SC 29414
}

\begin{abstract}
AdDitional IndEX words. Citrullus, molecular markers, Fusarium, RAPD, ISSR, SCAR
Abstract. A genetic linkage map was constructed for watermelon using 117 recombinant inbred lines (RILs) ( $\left.F_{2} S_{7}\right)$ descended from a cross between the high quality inbred line 97103 [Citrullus lanatus var. lanatus (Thunb.) Matsum. \& Nakai] and the Fusarium wilt (races 0, 1, and 2) resistant U.S. Plant Introduction (PI) 296341 (C. lanatus var. citroides). The linkage map contains 87 randomly amplified polymorphic DNA (RAPD) markers, 13 inter simple sequence repeat (ISSR) markers, and four sequenced characterized amplified region (SCAR) markers. The map consists of 15 linkage groups. Among them are a large linkage group of 31 markers covering a mapping distance of $277.5 \mathrm{cM}$, six groups each with 4 to 12 markers covering a mapping distance of 51.7 to $172.2 \mathrm{cM}$, and eight small groups each with 2-5 markers covering a mapping distance of 7.9 to $46.4 \mathrm{cM}$. The map covers a total distance of $1027.5 \mathrm{cM}$ with an average distance of $11.7 \mathrm{cM}$ between two markers. The map is useful for the further development of quantitative trait loci (QTLs) affecting fruit qualities and for identification of genes conferring resistance to F usarium wilt (races 0,1 and 2). The present map can be used for further construction of a reference linkage map for watermelon based on an immortalized mapping population with progenies homozygous for most gene loci.
\end{abstract}

Watermelon (Citrullus lanatus var. lanatus) accounts for $2 \%$ of the world area devoted to vegetable crops (FAO, 1995). China is the greatest producer and consumer of this crop. More than 57 million tons of watermelons were produced in China during 2001 (China Agricultural Department, 2002). In the United States watermelon production has increased from 1.2 million tons in 1980 to 3.8 million tons in 2001 with a farm value of $\$ 271$ million (U.S. Dept. of Agriculture, 2002). Cultivated watermelon is susceptible to a large number of fungal, bacterial and viral diseases that reduce yield and affect fruit quality (Levi et al., 2000; Netzer and Martyn, 1989; Sowell and Pointer, 1962). There is a great need to enhance watermelon for disease and pest resistances. Saturated genetic linkage maps are useful in identifying gene loci controlling horticultural traits and disease or pest resistances (Santra et al., 2000; Tuinstra, 1996). Linkage maps are also useful for positioning and tagging genes of interest to facilitate marker assisted selection (Hämäläinen et al., 1997; Martin et al., 1993).

Cultivated watermelon $(2 n=2 x=22)$ (Shimotsuma, 1963) has a narrow genetic base reflected by low isozyme (Navot and Zamir, 1987) and DNA polymorphisms among cultivars (Lee et al., 1996; Levi et al., 2001a; Zhang and Rhodes, 1993a). Thus, wide crosses between watermelon (C. lanatus var. lanatus) cultivars and U.S. Plant Introductions (PIs) of the related subspecies $C$. lanatus var. citroides are useful in producing polymorphic markers and in development of an initial linkage map for watermelon. A map derived from a wide cross can be used to anchor markers linked to horticultural quality loci identified in an $\mathrm{F}_{2}$ population lacking DNA polymorphisms. Navot and Zamir (1986) reported the first linkage map for watermelon derived from $C$. lanatus $\times C$. colocynthis. Their linkage map has 24 loci (includ-

Received for publication 15 Apr. 2003. Accepted for publication 15 Oct. 2003. This project was funded in part by the Natural Science Foundation of China (30070527), Chinese High-tech Program 2001AA241174 and the Natural Science Foundation of Beijing (5991017).

1Corresponding author; e-mail xuyong@nercv.com. ing 22 isozyme loci, the locus for fruit bitterness, and the locus for flesh color) segregating in seven linkage groups, and cover $354 \mathrm{cM}$. Using randomly amplified polymorphic DNA (RAPD) markers, Hashizume et al. (1996) constructed a linkage map of 11 linkage groups that covers $524 \mathrm{cM}$. The map was derived from a backcross population [an inbred line $\{(\mathrm{H}-7 ;$ C . lanatus $)$ $\mathrm{X}$ a wild accession (SA-1; C. lanatus) $\}$ x H-7]. Xu et al. (2000) constructed a genetic linkage map for watermelon using an $\mathrm{F}_{2}$ population derived from a cross of the high quality inbred line 97103 (developed at the National Engineering Research Center for Vegetables, Beijing) (C. lanatus var.lanatus) and PI 296341Fusarium resistant (FR). This PI showed resistance to race 0, 1, and 2 of Fusarium oxysporum f. Sp. niveum (Martyn and Netzer, 1991; Zhang and Rhodes, 1993b). That map covers $1203.2 \mathrm{cM}$ and consists of 85 randomly amplified polymorphic DNA(RAPD) markers, three simple sequence repeat (SSR) markers, three isozymes, four morphological markers, and a sequenced characterized amplified region (SCAR) marker closely linked $(1.6 \mathrm{cM})$ to the Fusarium wilt (Race 1) locus. Hawkins et al. (2001) constructed two linkage maps using $\mathrm{F}_{2}$ and $\mathrm{F}_{3}$ populations derived from New Hampshire Midget (NHM) x PI 296341-FR. These maps have 26 and 13 RAPD markers segregating in two and in five linkage groups, covering 112.9 and $139 \mathrm{cM}$, respectively. Using a $\mathrm{BC}_{1}$ population derived from [(PI 296341-FR x NHM) x NHM] Levi et al. (2001b) constructed a linkage map of 155 RAPD markers segregating in 17 linkage groups and covering $1295 \mathrm{cM}$. Levi et al. (2002) constructed an additional linkage map using a testcross population [ [Griffin 14113 (C. lanatus var. citroides) $x \operatorname{NHM}(C$. lanatus var. lanatus)\} x U.S. PI 386015 (C. colocynthis)]. That map contains 169 markers segregating in 25 linkage groups and covering $1162.5 \mathrm{cM}$. Still, there has not been any study reporting construction of a linkage map for watermelon using a recombinant inbred line (RIL) population. This paper describes a genetic linkage map for watermelon using an immortalized RIL $\left(\mathrm{F}_{2} \mathrm{~S}_{7}\right)$ population with progenies that are homozygous for most alleles. The RIL population is descended from the same $\mathrm{F}_{2}$ population 
[high quality inbred line 97103 (C. lanatus var. lanatus) x PI 296341-FR (C. lanatus var. citroides)] used for constructing our initial linkage map (Fan et al., 2000; Xu et al., 2000).

\section{Materials and Methods}

Construction of RILs. An $\mathrm{F}_{1}$ plant [PI 296341-FR x high quality inbred line 97103] was self-pollinated to produce $200 \mathrm{~F}_{2}$ progeny. One-hundred and fifty $\mathrm{F}_{2}$ plants were self-pollinated through strict single-seed descent to obtain $117 \mathrm{~F}_{2} \mathrm{~S}_{7}$ RILs (Darvasi and Soller, 1995; Perin et al., 2000). The RILs were produced under strict conditions in the greenhouse to prevent any crosscontamination among inbred lines. Also, rigorous procedures were used for self-pollinating female flowers in each generation. To avoid competition among fruits on the same vine that can result in abortion of self-pollinated female flowers, all female flowers except one were removed from the vine. The selected female flower was covered with a white soft-paper bag a day before flower opening. On the following morning, the female flower was self-pollinated using 6 to 12 male flowers on the same vine. Then, the pollinated flower was covered with the same bag for two additional days. Pure RILs were confirmed through phenotype consistency and segregation of fruit qualities from generation to generation.

Plant Materials. Parental plants: PI 296341-FR and the high quality inbred line 97103 , their $\mathrm{F}_{1}$ hybrid, and $117 \mathrm{~F}_{2} \mathrm{~S}_{7}$ RIL plants were grown in the greenhouse. Three weeks after germination, young leaves $(10 \mathrm{~g})$ were collected from each line, and stored at $-80{ }^{\circ} \mathrm{C}$.

DNA ISOLATION. An improved CTAB procedure (Murry and Thompson, 1980) was used for isolation of DNA from young leaves.

DNA AMPLIFICATION CONDITIONS AND GEL-ELECTROPHORESIS. RAPD and ISSR primers (Table 1) were purchased from Shanghai Sangon Biological Engineering Technology and Service, Inc. (Shanghai, China). RAPD reactions were performed in $25-\mu \mathrm{L}$ solution containing $10 \mathrm{~mm} \mathrm{NaCl}, 50 \mathrm{~mm}$ Tris- $\mathrm{HCl}$ (pH 9), 1\% Triton-X-100, $0.01 \%$ gelatin, $2.0 \mathrm{~mm} \mathrm{MgCl}_{2}, 0.2 \mathrm{~mm}$ of each dATP, dCTP, dGTP, and dTTP (Sigma, St. Louis, Mo), $0.2 \mathrm{~mm}$ primer, 1 unit Taq DNAPolymerase (supplied in storage buffer A) (TaKaRa, Tokyo, Japan) and 10 ng of template DNA. Amplification reactions were carried out for 45 cycles in PE-480 Thermal

Table 1. The nucleotide sequence of RAPD and ISSR primers and the number and size (bp) of bands (markers) produced by eachprimer used in the mapping analysis. The size (bp) of each band that could not be mapped (unmapped bands), and the size of bands skewed towards PI 296341 (SA), or towards 97103 (SB). Annealing temperature in PCR reactions was $37 \mathrm{oC}$ for all RAPD primers, and 54, 59, 59, and 62 oC, for ISSR primers $824,835,842$ and 856 , respectively.

\begin{tabular}{|c|c|c|c|c|c|c|}
\hline Primer & Sequence & $\begin{array}{l}\text { No. of } \\
\text { bands }\end{array}$ & $\begin{array}{l}\text { Band } \\
\text { size }\end{array}$ & $\begin{array}{l}\text { Unmapped } \\
\text { bands }\end{array}$ & SA & SB \\
\hline$\overline{\mathrm{A} 05}$ & AGGGGTCTTG & 1 & $800 z$ & & & \\
\hline A07 & GAAACGGGTG & 1 & 1100 & & & \\
\hline A08 & GTGACGTAGG & 2 & 1,100ay, 1,600 & & & 1,600 \\
\hline A10 & GTGATCGCAG & 2 & $500,1,031 \mathrm{a}$ & 500 & 500 & \\
\hline A12 & TCGGCGATAG & 1 & 600 & & & \\
\hline A18 & AGGTGACCGT & 1 & 1,600 & & & 1,600 \\
\hline B12 & CCTTGACGCA & 2 & $830 a, 1,100 a$ & & & \\
\hline B13 & TTCCCCCGCT & 1 & $1,400 \mathrm{a}$ & & & \\
\hline B20 & GGACCCTTAC & 2 & $900 \mathrm{a}, 1,200$ & & & \\
\hline $\mathrm{CO} 4$ & CCGCATCTAC & 1 & $1,300 \mathrm{a}$ & & & \\
\hline C06 & GAACGGACTC & 1 & 1,300 & & & \\
\hline C09 & CTCACCGTCC & 1 & $900 \mathrm{a}$ & & & \\
\hline C11 & AAAGCTGCGG & 1 & $550 \mathrm{a}$ & & & $550 \mathrm{a}$ \\
\hline E08 & TCACCACGGT & 2 & $600 a, 950 a$ & $950 \mathrm{a}$ & & \\
\hline F08 & GGGATATCGG & 1 & $2,500 \mathrm{a}$ & & & \\
\hline F09 & CCAAGCTTCC & 1 & 800 & 800 & & 800 \\
\hline $\mathrm{F} 15$ & CCAGTACTCC & 3 & $650,1,700,2,500$ & 2,500 & 650 & $2,500,1,700$ \\
\hline G10 & AGGGCCGTCT & 1 & $850 \mathrm{a}$ & & & \\
\hline $\mathrm{H} 02$ & TCGGACGTGA & 1 & $690 a$ & & & \\
\hline H07 & CTGCATCGTG & 3 & $540 a, 950$ & & & \\
\hline H08 & GAAACACCCC & 2 & $550,1,500$ & & & 1,500 \\
\hline H14 & ACCAGGTTGG & 1 & $600 \mathrm{a}$, & & & \\
\hline H17 & САСТСТССТG & 1 & $550 \mathrm{a}$ & & & \\
\hline I04 & CCGCCTAGTC & 1 & 1,200 & & & 1,200 \\
\hline $\mathrm{J} 11$ & ACTCCTGCGA & 2 & $1,200,700$ & & & $1,200,700$ \\
\hline K12 & TGGCCCTCAC & 2 & $400 \mathrm{a}, 900 \mathrm{a}$ & & & $900 \mathrm{a}, 400 \mathrm{a}$ \\
\hline K14 & CCCGCTACAC & 1 & 1,500 & & & 1,500 \\
\hline M05 & GGGAACGTGT & 1 & $1,200 \mathrm{a}$ & & & \\
\hline M07 & CCGTGACTCA & 3 & $400 \mathrm{a}, 590,750 \mathrm{a}$ & & & $590,400 \mathrm{a}$ \\
\hline M14 & AGGGTCGTTC & 1 & 250 & 250 & & \\
\hline M18 & CACCATCCGT & 2 & $620,850 a$ & & & 620 \\
\hline N09 & TGCCGGCTTG & 5 & $325 \mathrm{a}, 800 \mathrm{a}, 1,031 \mathrm{a}, 1,100,1,600$ & & & 1,100 \\
\hline N14 & TCGTGCGGGT & 3 & $600,800 \mathrm{a}, 850$ & & & \\
\hline $\mathrm{O} 03$ & CTGTTGCTAC & 1 & $480 \mathrm{a}$ & & & \\
\hline
\end{tabular}


Cycler (Perkin Elmer Cetus, Wellesley, Mass.), programmed for $60 \mathrm{~s}$ for DNA to denature at $94{ }^{\circ} \mathrm{C}, 60 \mathrm{~s}$ for DNA annealing at 37 ${ }^{\circ} \mathrm{C}$, and $120 \mathrm{~s}$ for primer extension at $72^{\circ} \mathrm{C}$. DNA amplification conditions for ISSR primers were the same as for the RAPD primers, except for the DNA annealing temperature optimized for each primer (Prevost and Wilkenson, 1999) (Table 1). PCRamplification products were separated by electrophoresis through $1.5 \%$ agarose gels with $0.5 \mu \mathrm{g} \cdot \mathrm{mL}^{-1}$ ethidium bromide in $1 \times$ TBE buffer. The gels were visualized under ultraviolet light and photographed (as shown in Fig. 1) using a Kodak Electrophoresis Documentation and Analysis System (EDAS) 120 (Kata Inc., Rochester, N.Y.). The molecular marker sizes of the amplification products were calculated using 100-bp DNA ladder standards (Gibco-BRL, Gaithersburg, Md).

Cloning And Sequencing of RAPD Fragments. RAPD fragments selected for cloning were excised from $1.5 \%$ agarose gel, and purified through a "Glass milk" kit (BioDev, Beijing). Purified fragments were cloned into pGEM T-easy vector following manufacturer instructions (Promega, Madison, Wis.), and suc- cessfully cloned RAPD fragments were sequenced. Based on sequence information, SCAR primers were designed for each fragment (Table 2). PCR-amplification conditions with SCAR primers were the same as for the RAPD and ISSR primers, except for DNA annealing temperature optimized for each primer pair (Table 2).

LINKAGE ANALYSIS OF MARKERS IN RILS. Data were analyzed using Mapmaker version 3.0 (Lander et al., 1987). Due to the low expected ratio $(0.8 \%)$ of heterozygous loci in the RILs $\left(\mathrm{F}_{2} \mathrm{~S}_{7}\right)$, the RI-SELF progeny (and not the $\mathrm{F}_{2}$ ) model was used for mapping data preparation. Markers were first grouped by using a minimum log of odds ratio (LOD) score of 4.0 and a maximum recombination value $(\mathrm{q})$ of 0.3 . For each linkage group, markers were ordered by using the "Order" command with a minimum LOD score of 3.0 and a maximum recombination value (q) of 0.25 . Markers ordered with low confidence were placed again using the "Try" command. The ordered marker sequences were confirmed using the "Ripple" command. Linkage maps were generated with the "Map" command using the "Kosambi" map

Table 1. Continued

\begin{tabular}{|c|c|c|c|c|c|c|}
\hline Primer & Sequence & $\begin{array}{l}\text { No. of } \\
\text { bands }\end{array}$ & $\begin{array}{l}\text { Band } \\
\text { size }\end{array}$ & $\begin{array}{l}\text { Unmapped } \\
\text { bands }\end{array}$ & SA & SB \\
\hline$\overline{\mathrm{O} 05}$ & CCCAGTCACT & 1 & 480 & & & 480 \\
\hline O08 & CCTCCAGTGT & 1 & 650 & 650 & & \\
\hline O13 & GTCAGAGTCC & 1 & $350 \mathrm{a}$ & & & \\
\hline O16 & TCGGCGGTTC & 2 & $475,550 \mathrm{a}$ & & $550 \mathrm{a}$ & \\
\hline P03 & CTGATACGCC & 1 & $600 \mathrm{a}$ & & & \\
\hline P17 & TGACCCGCCT & 3 & $940 \mathrm{a}, 1,000,2,400 \mathrm{a}$ & $940 \mathrm{a}$ & $940 \mathrm{a}$ & 1,000 \\
\hline Q05 & CCGCGTCTTG & 6 & $500,550,675 a$ & 550 & & 550,500 \\
\hline Q09 & GGCTAACCGA & 3 & $420,800 \mathrm{a}, 1,300$ & $420,800 \mathrm{a}, 1,300$ & & \\
\hline Q17 & GAAGCCCTTG & 1 & 1,500 & & 1,500 & \\
\hline R05 & GACCTAGTGG & 3 & $650,750,2,100 a$ & $2,100 \mathrm{a}$ & & \\
\hline S01 & CTACTGCGCT & 1 & 1,100 & 1,100 & & 1,100 \\
\hline S09 & TCCTGGTCCC & 2 & $650,3,000$ & $650,3,000$ & & 650 \\
\hline $\mathrm{S} 15$ & CAGTTCACGG & 1 & $1,000 \mathrm{a}$ & $1,000 \mathrm{a}$ & & \\
\hline $\mathrm{T} 13$ & AGGACTGCCA & 2 & $500,850 a$ & 500 & & \\
\hline T17 & CCAACGTCGT & 2 & $800,1,200 \mathrm{a}$ & & & \\
\hline V03 & СТCССТGCAA & 1 & 800 & & & \\
\hline X01 & CTGGGCACGA & 2 & $650 a, 900 a$ & & $900 a$ & \\
\hline X04 & CCGCTACCGA & 2 & $450,1,100$ & 1,100 & & 450 \\
\hline $\mathrm{X} 20$ & CCCAGCTAGA & 1 & 700 & & & \\
\hline Z01 & TCTGTGCCAC & 1 & 2,100 & & & \\
\hline $\mathrm{Z} 03$ & CAGCACCGCA & 4 & $250 \mathrm{a}, 750,900 \mathrm{a}$ & $1,200 \mathrm{a}$ & & \\
\hline Z04 & AGGCTGTGCT & 2 & $1,200 \mathrm{a}$ & & & \\
\hline $\mathrm{Z10}$ & CCGACAAACC & 2 & $900 \mathrm{a}, 1,600 \mathrm{a}$ & & & $1,900,500 \mathrm{a}$ \\
\hline $\mathrm{Z} 12$ & TCAACGGGAC & 3 & $850,1,500,1,800$ & 1,800 & & 1,500 \\
\hline $\mathrm{Z} 16$ & TCCCCATCAC & 1 & $500 \mathrm{a}$ & & & \\
\hline AH03 & GGTTACTGCC & 2 & $1,031 \mathrm{a}, 1,600 \mathrm{a}$ & $1,031 \mathrm{a}$ & & $1,031 \mathrm{a}$ \\
\hline AH08 & TTCCCGTGCC & 1 & $500 \mathrm{a}$ & & & \\
\hline AH12 & TCCAACGGCT & 1 & 2,000 & 2000 & & 2,000 \\
\hline AH13 & TGAGTCCGCA & 1 & $1,200 \mathrm{a}$ & & $1,200 \mathrm{a}$ & \\
\hline AI15 & GACACAGCCC & 1 & $850 \mathrm{a}$ & & & \\
\hline AL03 & CCCACCCTTG & 1 & $800 \mathrm{a}$ & & & \\
\hline AL11 & GTCACGTCCT & 1 & $650 \mathrm{a}$ & & & \\
\hline 824 & ТСТСТСТСТСТстСТСG & 1 & 1,375 & & & 1,375 \\
\hline 835 & AGAGAGAGAGAGAGA-GYC & $\mathrm{C} 10$ & $\begin{array}{l}209,210,220,298,328 a \\
370,430,480,565,730\end{array}$ & 480,730 & 220 & $209,210,430$ \\
\hline 842 & GAGAGAGAGAGAGAGA & AYG & 2 & $525,1,500 a$ & & \\
\hline 856 & ACACACACACACACAC & CCTA & 2 & $300,625 a$ & & 300 \\
\hline
\end{tabular}

zMarker donated by parental line 97103 .

yMarker donated by parental line PI 296341. 


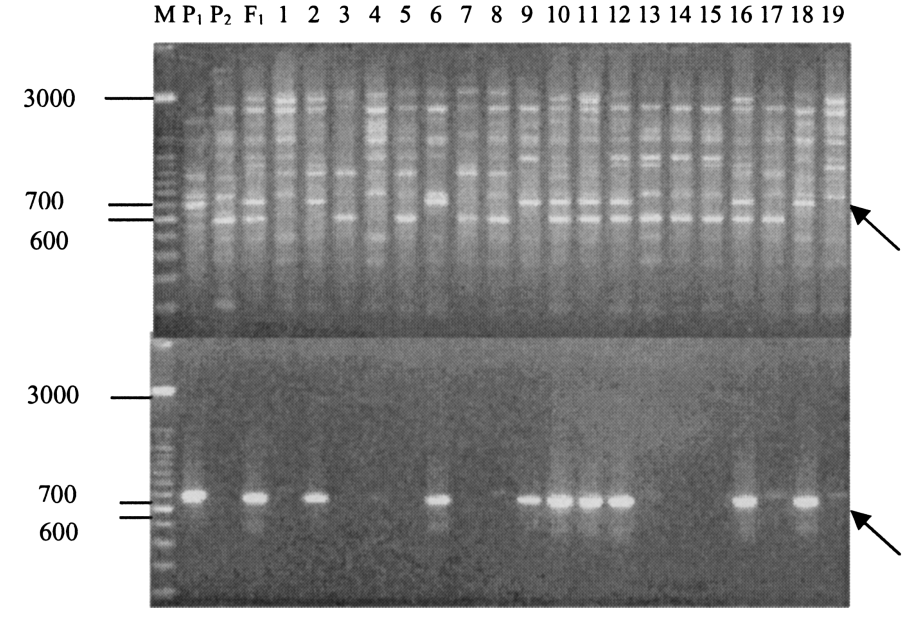

Fig. 1 Marker PO1-700a amplified with RAPD (upper figure) and SCAR primers (lower figure). The marker is missing in parent $97103\left(\mathrm{P}_{2}\right)$, but present in PI $296341\left(\mathrm{P}_{1}\right)$ and in the $\mathrm{F}_{1}$ hybrid and segregating among $\mathrm{F}_{8}$ progeny.

function. The "Error-Detection" command was used to identify possible marker scoring errors, and putative errors were re-tested. Chi-square tests were performed to check whether individual markers segregated randomly.

MARKER NOMENCLATURE. RAPD markers were designated by their serial number and their size. For example, the 800-bp marker produced by RAPD primer N14 is unique to PI 296341 and was designated as N14-800a. ISSR or SCAR markers were designated as ISSR or SC (respectively) followed by their serial number and their size. For example, the 525-bp marker produced by ISSR primer 842 (Table 1) is unique to inbred line 97103 and was designated as ISSR842-525, while the 600-bp marker produced by SCAR primer pair SCN04 (Table 2) is unique to inbred line 97103 and was designated as SCN04-600 (Fig. 2).

\section{Results and Discussion}

The RILs used in this study were produced under strict conditions in the greenhouse to prevent any cross-contamination among inbred lines. Pure RILs were confirmed through phenotype consistency and segregation of certain fruit qualities from generation to generation.

Of the initial $150 \mathrm{~F}_{2}$ plants that were self-pollinated, $117 \mathrm{RILs}$ $\left(\mathrm{F}_{2} \mathrm{~S}_{7}\right)$ could be used for genetic analysis and construction of a linkage map. Twenty-nine RIL lines were lost along the strict single-seed decent procedure while four RILs had a small seed number. The RIL-based map contains 15 linkage groups. Among them, a large linkage group of 31 markers covering a mapping distance of 277.5 $\mathrm{cM}$, and six groups, each with four to twelve markers covering a mapping distance of 51.7-172.2 cM. Additionally, eight small groups, each with two to five markers covering a mapping distance of 7.9-46.4 cM (Table 3, Fig. 2). The map contains 127 markers covering a total distance of 1,027.5 $\mathrm{cM}$ with an average distance of $11.7 \mathrm{cM}$ between two markers (Table 3, Fig. 2).

The largest linkage group $(277.5 \mathrm{cM})$ detected in the linkage map (Table 3$)$ is consistent with a large group $(208.3 \mathrm{cM})$ in the linkage map derived from an $\mathrm{F}_{2}$ population developed from the same parents (Fan et al., 2000). Marker SCP01-700 (Fig. 1), which is closely linked $(1.6 \mathrm{cM})$ to Fusarium wilt (race 1) resistance gene (Xu et al., 2000) is mapped on this large group in both maps (Fig. 2; Group I). A large linkage group was also detected in maps constructed for watermelon using $\mathrm{BC}_{1}$ or testcross populations (207.9 cM and $225.6 \mathrm{cM}$, respectively) (Levi et al., 2001b and 2002). Marker SCP01-700 (Fig. 1) is closely linked (0.5 cM) to 'Issr835-328a' on the largest linkage group (Fig. 2; Group I). These two markers are also located on the largest linkage group in the map constructed for watermelon using a testcross population (Levi at al., 2002). However, in the testcross-based map the distance between the two markers is wider $(28.2 \mathrm{cM})$. Marker $\mathrm{SCP} 01-700$ is also located on the largest linkage group in the backcross-based map (A. Levi, unpublished data). In that map it is closely linked (2.6 cM) to marker G10-850 (Levi et al. 2001) as in the present map (5.1 cM) (Fig. 2; Group I). These results indicate that the largest linkage group in all maps represents the same chromosome. Additional studies are needed to determine whether this linkage group represents a large chromosome, or a chromosomal region with repetitive sequences that result in a high number of polymorphic RAPD and ISSR markers.

One-hundred and twelve RAPD, fifteen ISSR, and five SCAR markers (Tables 1 and 2) were used for constructing the linkage map (Fig. 2). The mapping markers were uniquely present in one of the donor parents (PI 296341 or 97103) and in the $F_{1}$ hybrid, and segregated among the RIL progeny (Fig. 1). Of the mapping markers, 62 were unique to PI 296341 and 65 were unique to the inbred line 97103.

Map Construction. One hundred and four markers (78.8\%) out of the 132 markers analyzed could be placed on linkage groups. Twenty-five of the 112 RAPD markers, two of the 15 ISSR markers (Table 1), and one of five SCAR markers (Table 2) could not be ordered on the map following grouping of markers in linkage groups. Of the 15 linkage groups, 9 consisted of markers from both parents (PI 296341 and 97103), while four small linkage groups (VI, VIII, X, and XIII) consist of markers unique to 97103, and two linkage groups (XII and XIV) have markers unique to PI 296341 (Table 3, Fig. 2).

The ISSR and SCAR markers (Fig. 1) are highly reproducible following optimization of their annealing temperature in PCR reactions (Tables 1 and 2) (Levi et al., 2002; Prevost and Wilkenson, 1999). Furthermore, all SCAR markers were highly consistent with those produced by their corresponding RAPD primer, as shown for marker SCP01-700 (Fig. 1). The 13 ISSR markers (Table 1) were mapped on nine linkage groups, while the four SCAR markers (Table 2) were mapped on two linkage groups (Fig. 2).

Table 2. SCAR markers, their forward and revers primers and their annealing temperature used in the PCR amplification reactions.

\begin{tabular}{|c|c|c|c|}
\hline Marker & Forward primer & Reverse primer & $\begin{array}{l}\text { Anealing } \\
\text { temp }\left({ }^{\circ} \mathrm{C}\right)\end{array}$ \\
\hline SCK14-1500 & 5'-CCCGCTACACCTGGAC & 5'-CCCGCTACACGAGTAGA & 55 \\
\hline SCN04-600 & 5'-GATGCTTTCATAAGGAAG & 5'-GACCGACCCATCCTATTG & 60 \\
\hline SCT19-1600 & 5'-GTCCGTATGGCAAAGTTGG & 5'-GTCCGTATGGGGATCAG & 60 \\
\hline SCP01-570 & 5'-GTAGCACTCCAACATCAAAATCGG & 5'-GTAGCACTCCCAGTGAAATTTCTA & 60 \\
\hline SCP01/700 & 5'-GTAGCACTCCAACATTTATTCTAATTC & 5'-GTAGCACTCCCAACTCATACAAAT & 60 \\
\hline
\end{tabular}


I
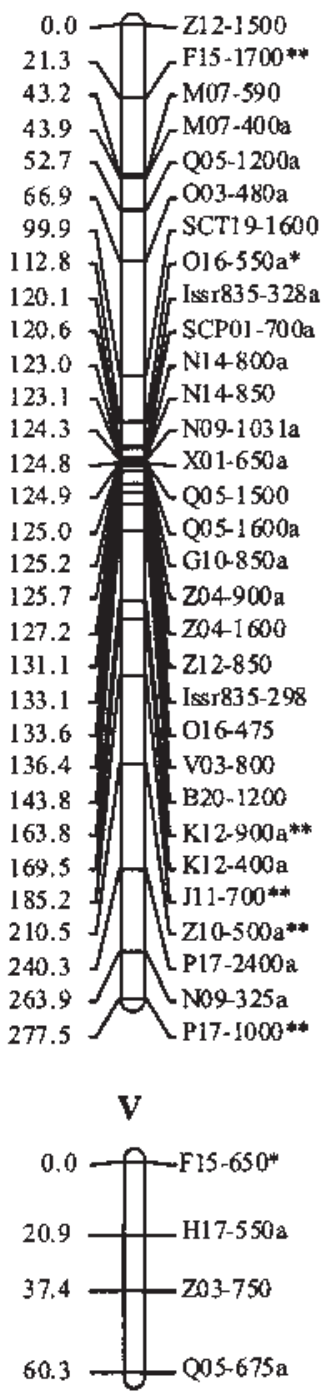

IX

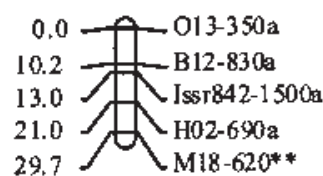

II

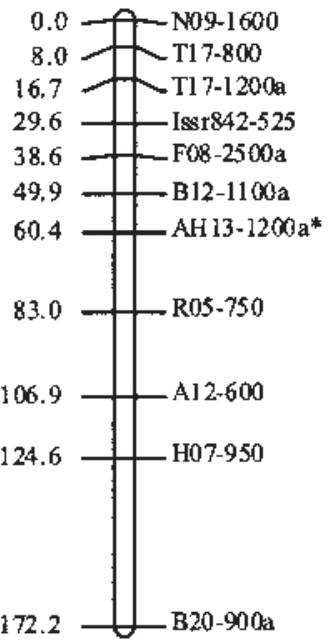

\section{XIII}

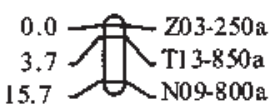

VI
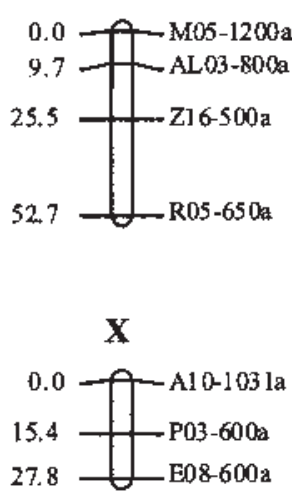

III

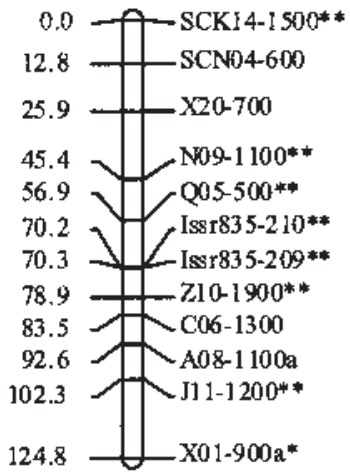

XIV

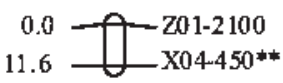

VII
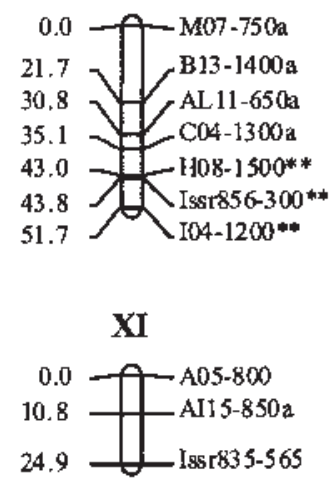
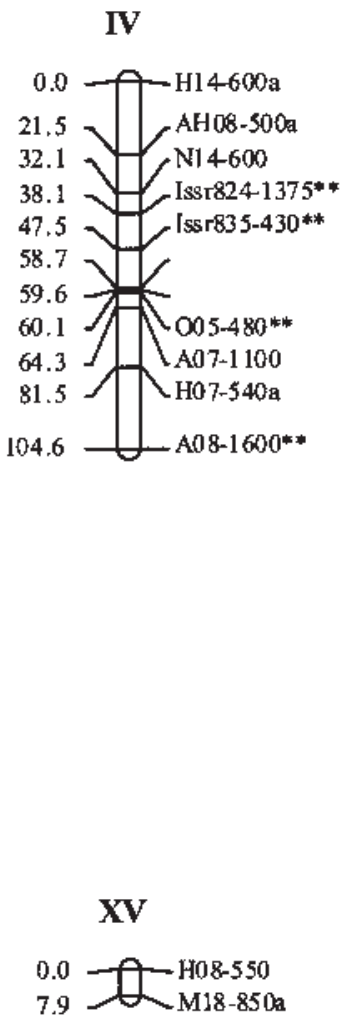

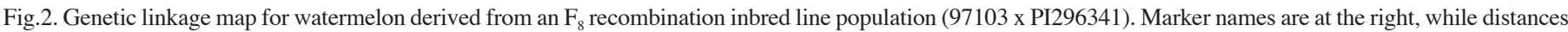
between adjacent marker (in cM) are at the left of each linkage group. *Indicates markers skewed towards PI296341; **Indicates markers skewed towards 97103.

Marker SEgRegation. Of the 132 markers analyzed, 37 (28.0\%) showed segregation patterns skewed away from a 1:1 ratio at $P=0.05$. Of these, $30(81.7 \%)$ markers skewed toward 97103, while 7 (18.9\%) markers skewed toward PI 296341 (Tables 1 and 3). Of the 30 markers skewed toward 97103, eight markers (K14-1500, S1-1100, C11-550a, F9-800, F15-2500, S9-650, AH12-2000, SCP01-570) could not be mapped, five markers (F15-1700, K12-900a, Z10-500a, P17-1000, J11-700) were assigned to linkage group I, seven markers (SCK14-1500, N09-1100, Q05-500, Issr835-210, Issr835-209, Z10-1900, J11-1200) were assigned to linkage group III, five markers (Issr824-1375, Issr856430, O05-480, A18-1600, A08-1600) were assigned to linkage group IV, three markers (H08-1500, Issr856-300, I04-1200) were assigned to linkage group X, one marker (M18-620) was assigned to linkage group XII, and one marker (X04-450) was assigned to linkage group VI. Of the seven markers skewed toward 97103, one marker (A10-500) could not be mapped, while O16-550a, AH13-1200a, X01-900a, Q17-1500, F15-650 were assigned to linkage group I, II, III, IV, and VIII, respectively. Large number of markers $(47.5 \%$ and $48.0 \%)$ showed skewed segregation pattern in an $\mathrm{F}_{2}$ and $\mathrm{F}_{3}$ populations derived from a cross between PI 296341 and NHM (Hawkins et al., 2001). Many markers (25.7\% and $18.0 \%$, respectively) were also skewed in backcross and testcross populations used for constructing a linkage maps for watermelon (Levi et al., 2001b, 2002). Skewed segregation has been observed in populations derived from wide crosses (Zamir and Tadmor, 1986), and might be a result of a meiotic drive (Sandler and Novitski, 1957). 
Table 3. Marker distribution among linkage groups of the RIL (F2S7) population (97103 x PI 296341).

\begin{tabular}{lcccc}
\hline $\begin{array}{l}\text { Linkage } \\
\text { group }\end{array}$ & $\begin{array}{c}\text { No. of } \\
\text { markers }\end{array}$ & $\begin{array}{c}\text { Length } \\
(\mathrm{cM})\end{array}$ & $\begin{array}{c}\text { Avg } \\
\text { distance } \\
(\mathrm{cM})\end{array}$ & $\begin{array}{c}\text { No. of } \\
\text { skewed } \\
\text { markers }\end{array}$ \\
\hline I & 31 & 277.5 & 9.25 & $1^{\mathrm{z}}, 5^{\mathrm{y}}$ \\
II & 11 & 172.2 & 17.22 & $1^{\mathrm{z}}$ \\
III & 12 & 124.8 & 11.35 & $1^{\mathrm{z}}, 7^{\mathrm{y}}$ \\
IV & 11 & 104.6 & 10.46 & $1^{\mathrm{z}}, 5^{\mathrm{y}}$ \\
V & 4 & 60.3 & 20.1 & $1^{\mathrm{z}}$ \\
VI & 4 & 52.7 & 17.57 & --- \\
VII & 7 & 51.7 & 8.62 & $3^{\mathrm{y}}$ \\
VIII & 4 & 46.4 & 15.47 & --- \\
IX & 5 & 29.7 & 7.43 & $1^{\mathrm{y}}$ \\
X & 3 & 27.8 & 13.9 & --- \\
XI & 3 & 24.9 & 12.45 & --- \\
XII & 2 & 19.7 & 19.7 & $1^{\mathrm{z}}$ \\
XIII & 3 & 15.7 & 17.85 & --- \\
XIV & 2 & 11.6 & 11.6 & $1^{\mathrm{y}}$ \\
XV & 2 & 7.9 & 7.9 & --- \\
Total & 104 & $1,027.50$ & $11.54 \mathrm{x}$ & 28 \\
\hline
\end{tabular}

${ }^{\mathrm{z}}$ Markers skewed toward PI 296341.

yMarkers skewed toward 97103.

xAverage distance between two markers.

In an earlier study we constructed a linkage map using an $\mathrm{F}_{2}$ population derived from the same parents (PI $296341 \times 97103$ ) of the $\mathrm{F}_{2} \mathrm{~S}_{7}$ RILs in this study. The $\mathrm{F}_{2}$-based map covers $1203.2 \mathrm{cM}$ (Fan et al., 2000; Xu et al., 2000) with an average genetic distance of $12.35 \mathrm{cM}$ between two markers. The present RIL map covers a smaller genetic distance $(1027.5 \mathrm{cM})$ with an average distance of $11.7 \mathrm{cM}$ between two markers. A higher number of recombination events (wider genetic distances) is expected in the $\mathrm{F}_{2} \mathrm{~S}_{7}$ RILs (due to recurring meiosis events through eight generations) as compared with one meiosis event for the $\mathrm{F}_{2}$ population (Perin et al., 2000). These results might be due to using different set of markers in the $\mathrm{F}_{2}$ and the RIL maps. It is possible that some regions covered by markers in the $\mathrm{F}_{2}$-based map are more prone to recombination events as compared with regions covered by markers in the RIL-map. However, the average linkage distances between two markers in the linkage maps developed for watermelon using a backcross or a testcross population (Levi et al., 2001b, 2002) are smaller (9.3 and $8.1 \mathrm{cM}$, respectively) than these in the $\mathrm{F}_{2}$ and the RIL maps (12.35 and $11.7 \mathrm{cM}$, respectively). Furthermore, most large linkage groups in backcross map and a few in the testcross map contained dense regions with no or low recombination events ( 0 to $2.8 \mathrm{cM}$ between 2 to 8 markers) (Levi et al., 2001, 2002). Higher recombination events are expected in RIL and $\mathrm{F}_{2}$ populations than in backcross or testcross populations (Perin et al., 2000).

Great efforts have been devoted to develop immortal mapping populations, including doubled haploids (DH) and RILs in many important crop plants (Burr et al., 1988). RILs are being used for genetic linkage mapping in related cucurbit species, including melon (Perin et al., 2000) and cucumber (Park et al., 2000; Staub et al., 2003). The RIL population used in this study is segregating for Fusarium wilt resistance (Xu et al., 2000). Additionally, it is segregating for fruit qualities (fruit shape, fruit size, rind color, rind thickness, flesh color, flesh sugar content, and days to fruit maturity). Fruit qualities are currently being scored using the RIL population (Y. Xu, unpublished data), and will be used for QTL analysis. The wide genetic differences between the parents PI 296341 (C. lanatus var. citroides) and the watermelon inbred line 97103 provide sufficient number of polymorphic loci that can be mapped with high confidence. Co-dominant markers including SSRs, SCARs, and RFLPs are being developed (Y. $\mathrm{Xu}$ and $\mathrm{A}$. Levi, unpublished data) and will be used to merge all linkage maps for watermelon with the RIL-based map. The RILs can also be useful for accurate positioning of genes conditioning disease or pest resistance, fruit qualities e.g., flesh color and lycopene content in watermelon (A. Davis and Y. Tadmor, personal communication). The RIL population is being released by The National Engineering Research Center for Vegetables, Beijing, China (Yong Xu; xuyong@nercv.com).

\section{Literature cited}

Burr, B., F.A. Burr, K.H. Thompson, M.C. Albertson, and C.W. Stuber. 1988. Gene mapping with recombinant inbreds in maize. Genetics 118:519-526.

China Agricultural Yearbook for 2001. 2002. China Agr. Dept., Beijng, China. No.125.

Darvasi, A. and M. Soller. 1995. Advanced intercross lines, an experimental population for fine genetic mapping. Genetics 141:1199-1207.

Fan, M., Y. Xu, H.Y. Zhang, G.B. Kang, Y.J. Wang, and H. Chen. 2000. Identification of quantitative trait loci associated with fruit traits in watermelon [Citullus lanantus (Thaunb) mansf] and analysis of genetic effects. Acta Genet. Sinica. 27:902-910.

FAO. 1995. Production year book for 1994. Food Agr. Org. United Nations, Rome.

Hämäläinen, J.H., K.N. Watanabe, J.P.T. Valkonen, A. Arihara, R.L. Plaised, L. Miller, and S.A. Slack. 1997. Mapping and marker-assisted selection for a gene for extreme resistance to potato virus Y. Theor. Appl. Genet. 94:192-197

Hashizume, T., I. Skimamoto, Y. Harushima, M. Yui, T. Sato, T. Imai, and M. Hirai. 1996. Constrution of a linkage map for watermelon [Citrullus lanatus (Thunb) Matsum \& Nakai] using RAPD. Euphytica 90:265-273.

Hawkins, L.K., F. Dane, T.L. Kubisiak, B.B. Rhode, and R.L. Jarret. 2001. Linkage mapping in a watermelon population segregating for Fusarium wilt resistance. J. Amer. Soc. Hort. Sci. 126:344-350.

Lander, E.S., P. Green, J.Abrahamson, A. Barlow, M.J. Daly, S.E. Lincoln, L. Newbur. 1987. MAPMARKER: An interactive computer package for constructing primary genetic linkage maps of experimental and natural populations. Genomics 1:174-181.

Lee, S.J., J.S. Shin, and K.W. Park. 1996. Detection of genetic diversity using RAPD PCR and sugar analysis in watermelon (C. lanatus) germplasm. Theor. Appl. Genet. 92:719-725.

Levi, A., C.E. Thomas, A.P. Keinath, and T.C. Wehner. 2000. Estimation of genetic diversity among Citrullus accessions using RAPD markers. Acta Hort. 510:385-390.

Levi, A., C.E. Thomas, T.C. Wehner, and X. Zhang. 2001a. Low genetic diversity indicates the need to broaden the genetic base of cultivated watermelon. HortScience 36:1096-1101.

Levi, A, C.E. Thomas, T. Joobeur, X. Zhang, and A. Davis. 2002. A genetic linkage map for watermelon derived from a testcross population: (Citrullus lanatus var. citroides $\times$ C. lanatus var. lanatus) X Citrullus colocynthis. Theor. Appl. Genet. 105:555-563.

Levi, A., C.E. Thomas, X.P. Zhang, T. Joobeur, R.A. Dean, T.C. Wehner, and B.R. Carle. 2001b. A genetic linkage map for watermelon based on RAPD markers. J. Amer. Soc. Hort. Sci. 126:730-737.

Martin,G.B., S.H. Brommonschenkel, J. Chunwongse, A. Frary, M.W. Ganal, R. Spivey, T. Wu, E.D. Earle, and S.D. Tanksley. 1993. Mapbased cloning of a protein kinase gene conferring disease resistance in tomato. Science 262:1432-1436.

Martyn, R.D. and D. Netzer. 1991. Resistance to race 0, 1, and 2 of Fusarium wilt of watermelon in Citrullus sp. PI-296341-FR. HortScience 26:429-432.

Murry,H.G. and W.F. Thompson. 1980. Rapid isolation of high molecular weight plant DNA. Nucl. Acids Res. 8:4321-4325 
Navot, N. and D. Zamir. 1986. Linkage relationships of 19 protein-coding genes in watermelon. Theor. Appl. Genet. 72:274-278.

Navot, N. and D. Zamir. 1987. Isozyme and seed protein phylogeny of genus Citrullus (Cucurbitaceae). Plant Syst. Evol. 156:61-67.

Netzer, D. and R.D. Martyn. 1989. PI 296341, a source of resistance in watermelon to race 2 of Fusarium oxysporum f. sp. niveum. Plant Dis. 73:518.

Park, Y.H., S. Sensoy, C. Wye, R. Antonise, J. Peleman, and M.J. Havey. 2000. Agenetic map of cucumber composed of RAPDs, RFLPs, AFLPs, and loci conditioning resistance to papaya ringspot and zucchini yellow mosaic viruses. Genome 43:1003-1010.

Perin, C., L. Hagen, C. Dogimont, V. de Cunto, L. Lecomte, and M. Pitrat. 2000. Construction of a reference map of melon. Acta Hort. 510:367-374.

Prevost, A. and M.J. Wilkenson.1999. A new system of comparing PCR primers applied to ISSR finger-printing of potato cultivars. Theor.Appl. Genet. 98: 107-112.

Sandler, L. and E.M. Novitski. 1957. Meiotic drive as an evolutionary force. Amer. Naturalist 91:105-110.

Santra, D.K., M. Tekeoglu, M. Ratnaparkhe, W.J. Kaiser, and F.J. Muehlbauer. 2000. Identification and mapping of QTLs conferring resistance to ascochyta blight in chickpea. Crop Sci. 40:1606-1612.
Shimotsuma, M.1963. Cytogenetic and evolutionary studies in the genus Citrulls. Seiken Jiho 15:24-34.

Sowell, Jr., G. and G.R. Pointer. 1962. Gummy stem blight resistance of introduced watermelons. Plant Dis. Rptr. 46:883-885.

Staub, J.E., L.K. Crubaugh, and G. Fazio. 2003. Cucumber Recombinant Inbred Lines. Cucurbit Genet. Coop. Rpt. 25:1-2.

Tuinstra, M.R. 1996. Identification of quantitative trait loci associated with pre-flowering drought tolerance in sorghum. Crop Sci. 36: 1337-1344.

U.S. Department of Agriculture. 2002. Agricultural Statistics. U.S. Dept. Agr., Natl. Agr. Stat. Serv., Wash., D.C.

Xu,Y., H.Y. Zhang, G.B. Kang, Y.J. Wang, and H. Chen. 2000. Studies of molecular marker-assisted selection for resistance to Fusarium wilt in watermelon (Citrullus lanatus) breeding. Acta Genet. Sinica. 27:51-157.

Zamir, D. and Y. Tadmore. 1986. Unequal segregation of nuclear genes in plants. Bot. Gaz. 147:355-358.

Zhang, X.P. and B.B. Rhodes. 1993a. RAPD molecular marker in watermelon. HortScience 28:583.

Zhang, X.P. and B.B. Rhodes. 1993b. Inheritance of resistance to race 0, 1, and 2 of Fusarium oxysporum f. sp. niveum in watermelon (Citrullus sp. PI296341). Cucurbit Genet. Coop. Rpt. 16:77-78. 